\title{
Synthesis and optical characterization of porous $\mathrm{ZnO}$
}

\author{
K. SOWRI BABU*, A. RAMACHANDRA REDDY, Ch. SUJATHA, \\ K. VENUGOPAL REDDY, A. N. MALLIKA

\begin{abstract}
Department of Physics, National Institute of Technology Warangal, Warangal-506 004, Andhra Pradesh, India
\end{abstract}
Received: March 18, 2013; Revised: April 19, 2013; Accepted: May 03, 2013

(C) The Author(s) 2013. This article is published with open access at Springerlink.com

\begin{abstract}
In this paper, a simple and cheap method to prepare porous $\mathrm{ZnO}$ by using zinc nitrate, ethanol and triethanolamine (TEA) is reported. The as-prepared sample consisted of nano and micro pores. The sample was calcined at $300{ }^{\circ} \mathrm{C}, 400{ }^{\circ} \mathrm{C}$ and $500{ }^{\circ} \mathrm{C}$ with different heating rates. At $500{ }^{\circ} \mathrm{C}$, the nano pores disappeared but the sample maintained its micro porosity. Field emission scanning electron microscopy (FE-SEM) pictures confirmed that the size and growth of $\mathrm{ZnO}$ nanoparticles depended on the heating conditions. The infrared (IR) absorption peak of $\mathrm{Zn}-\mathrm{O}$ stretching vibration positioned at $457 \mathrm{~cm}^{-1}$ was split into two peaks centered at $518 \mathrm{~cm}^{-1}$ and $682 \mathrm{~cm}^{-1}$ with the change of morphology. These results confirmed that Fourier transform infrared (FT-IR) spectrum was sensitive to variations in particle size, shape and morphology. The photoluminescence (PL) spectrum of porous $\mathrm{ZnO}$ contained five emission peaks at $397 \mathrm{~nm}, 437 \mathrm{~nm}, 466 \mathrm{~nm}, 492 \mathrm{~nm}$ and $527 \mathrm{~nm}$. Emission intensity enhanced monotonously with increase of temperature and the change was rapid between temperatures of $300{ }^{\circ} \mathrm{C}$ and $500{ }^{\circ} \mathrm{C}$. This was due to the elimination of organic species and improvement in the crystallanity of the sample at $500{ }^{\circ} \mathrm{C}$.
\end{abstract}

Keywords: semiconductors; porous $\mathrm{ZnO}$; optical properties

\section{Introduction}

Materials exhibit novel and fascinating properties with reduction of size from bulk to nanometer scale. As far as the semiconductor nanoparticles are concerned, the increase in band gap has been observed when the particle size is comparable to or smaller than the excitonic Bohr radius. Consequently, the emission spectrum shows blue shift (shift towards lower wavelength) and it is called quantum confinement effect. Among the various known semiconductors, $\mathrm{ZnO}$ has several advantages compared to other

\footnotetext{
* Corresponding author.

E-mail: sowribabuk@gmail.com
}

wide-band-gap semiconductors. It has a direct band gap of $3.37 \mathrm{eV}$ and large exciton binding energy of $60 \mathrm{meV}$ at room temperature [1]. Due to these unique properties, it finds applications in antireflection coatings, transparent electrodes in solar cells, ultraviolet (UV) light emitters, diode lasers, varistors, piezoelectric devices, spin-electronics, surface acoustic wave propagation, and also in sensing of gas [2]. It is well known that nanostructures have very good sensitivity with respect to size, shape, type of material and preparation techniques. In the case of $\mathrm{ZnO}$, it is able to satisfy above properties because it can be easily synthesized in various shapes like particles, rods, needles, shells, tubes, wires, nails, belts, combs, propellers, springs, tetrapods, etc. [3-8].

Apart from the above variety of structures, porous 
$\mathrm{ZnO}$ can also be prepared. Porous $\mathrm{ZnO}$ has some specific advantages such as high surface area, chemical and photochemical stability, uniformity in pore size, shape selectivity, and rich surface chemistry [9]. The high surface area of porous $\mathrm{ZnO}$ makes its surface more active. The highly active surface would increase the probability of interaction of gases with the semiconductor, which in turn increases the sensitivity of the material [10]. So, the material has found a variety of promising applications such as catalysts, nano-sieve filters, dye sensitized solar cells, bio- and electrochemical sensors, bone-replacement materials and also in gas sensors $[9,11,12]$. For example, for dye sensitized solar cells, $\mathrm{ZnO}$ thin films should be porous and have high specific surface area for obtaining high conversion efficiency of light into current [13]. Recently, some attention has been paid to the synthesis of porous $\mathrm{ZnO}$ by using various methods such as thermal decomposition method, template assisted methods, hydrothermal method, solid-vapor process, radio frequency sputtering, electrochemical deposition, etc. [13-15]. To the best of our knowledge, an easy and economical method to prepare porous $\mathrm{ZnO}$ is not addressed so far. So, because of the importance of porous $\mathrm{ZnO}$ in various applications mentioned above, the following work is taken up.

In this work, a simple and cheap method to prepare nanoporous $\mathrm{ZnO}$ using zinc nitrate, ethanol and triethanolamine (TEA) is reported. The as-prepared sample was calcined at $300{ }^{\circ} \mathrm{C}, 400{ }^{\circ} \mathrm{C}$ and $500{ }^{\circ} \mathrm{C}$ and studied with their structural and optical properties. The sample was characterized with X-ray diffraction (XRD), field emission scanning electron microscopy (FE-SEM), ultraviolet-visible (UV-Vis) spectrophotometer, and Fourier transform infrared (FT-IR) and photoluminescence (PL) spectrometers to study their structural and optical properties.

\section{Experimental procedures}

The preparation of porous $\mathrm{ZnO}$ is as follows. $0.53 \mathrm{~g}$ of $\mathrm{Zn}\left(\mathrm{NO}_{3}\right)_{2} \cdot 6 \mathrm{H}_{2} \mathrm{O}$ was dissolved in ethanol and stirred on magnetic hot plate until it became clear and stable. To this solution, a few drops of TEA were added and stirring was continued for one more hour at room temperature. In the next step, the temperature of the hot plate was increased to $80{ }^{\circ} \mathrm{C}$ to evaporate the solvent. Then, the solution was converted into a gel. The gel was subsequently swelling into foam and underwent a self-propagating combustion reaction on the hot plate itself to give fine powder. The combustion took place within few seconds and the resulted powder was of dark brown color. Afterwards, the sample was calcined at $300{ }^{\circ} \mathrm{C}$ and $500{ }^{\circ} \mathrm{C}$ with a heating rate of $2{ }^{\circ} \mathrm{C} / \mathrm{min}$ in a programmable furnace. As the temperature was increased to $500{ }^{\circ} \mathrm{C}$, the color of the sample changed from brown to white. To know the influence of heating conditions on the size of the particles and growth, the sample was also calcined at $400{ }^{\circ} \mathrm{C}$ with a heating rate of $1{ }^{\circ} \mathrm{C} / \mathrm{min}$.

XRD measurements were taken on Inel XRG 3000 diffractometer equipped with Cobalt $\mathrm{K} \alpha \quad(\lambda=$ $1.78897 \AA)$ radiation $(15 \mathrm{~mA}, \quad 30 \mathrm{kV})$. The morphology of the sample was studied by using ZEISS FE-SEM. Absorption spectra were acquired on Analyticazena (Specord 205) UV-Vis spectrophotometer. FT-IR spectra of the sample were recorded on Bruker Optics FT-IR Spectrometer Model: Tensor 27. PL measurements were performed on Jobin Yuon spectrofluorometer with $450 \mathrm{~W}$ xenon arc lamp.

\section{Results and discussion}

\subsection{XRD analysis}

Figure 1 shows the XRD patterns for the as-prepared porous $\mathrm{ZnO}$ and porous $\mathrm{ZnO}$ calcined at $300{ }^{\circ} \mathrm{C}$ and $500{ }^{\circ} \mathrm{C}$. This picture depicts the characteristic peaks (100), (002), (101), (102), (110), (103), etc., which correspond to the wurtzite $\mathrm{ZnO}$ structure. The broadening of these peaks decreases continuously, which is an indication of the increase in particle size and improved crystallanity with a rise of temperature. The change is drastic as the temperature increases from $300{ }^{\circ} \mathrm{C}$ to $500{ }^{\circ} \mathrm{C}$. The crystallite size of the sample is calculated using Debye-Scherrer formula:

$$
D=\frac{0.9 \lambda}{\beta \cos \theta}
$$

where $D$ is the particle diameter; $\lambda$ is the wavelength of the X-ray used; $\beta$ is the FWHM (full width at half maximum); and $\theta$ is the diffraction angle. The crystallite size values for the as-prepared porous $\mathrm{ZnO}$ and the samples calcined at $300{ }^{\circ} \mathrm{C}$ and $500{ }^{\circ} \mathrm{C}$ are $3 \mathrm{~nm}, 6 \mathrm{~nm}$ and $43 \mathrm{~nm}$, respectively. This drastic change in crystallite size indicates that up to $300{ }^{\circ} \mathrm{C}$ only the progress of crystallization from amorphous state occurs and further growth takes place above 




Fig. 1 Typical XRD patterns of (a) the as-prepared porous $\mathrm{ZnO}$ and porous $\mathrm{ZnO}$ annealed at (b) $300{ }^{\circ} \mathrm{C}$ and (c) $500{ }^{\circ} \mathrm{C}$.

$300{ }^{\circ} \mathrm{C}$. Hence well crystallized $\mathrm{ZnO}$ is formed at $500{ }^{\circ} \mathrm{C}$ and the color of the sample turns out from brown to white. It can also be seen from Fig. 1 that diffraction peaks of $\mathrm{ZnO}$ shift towards the higher angle side compared to the as-prepared porous $\mathrm{ZnO}$ with a rise of temperature. This implies that $\mathrm{ZnO}$ nanoparticles are under compressive stress.

\section{2 FE-SEM analysis}

The FE-SEM micrographs of the as-prepared porous $\mathrm{ZnO}$ and porous $\mathrm{ZnO}$ annealed at $500{ }^{\circ} \mathrm{C}$ are presented in Fig. 2. The as-prepared sample contains nano and micro pores with diameters ranging from a few nanometers to micrometers. The porous $\mathrm{ZnO}$ is shown in Fig. 2(b) representing the nano pores. But, such nano pores are not detected when it is calcined at $500{ }^{\circ} \mathrm{C}$. From the FE-SEM micrograph in Fig. 2(d), the average particle size of the porous $\mathrm{ZnO}$ calcined at $500{ }^{\circ} \mathrm{C}$ comes out to be $47 \mathrm{~nm}$. This value is in good agreement with the value obtained from the XRD data.

\section{3 UV-Vis analysis}

The UV-Vis absorbance spectra of the as-prepared porous $\mathrm{ZnO}$ and samples annealed at $300{ }^{\circ} \mathrm{C}$ and $500{ }^{\circ} \mathrm{C}$ are shown in Fig. 3. The as-prepared porous $\mathrm{ZnO}$ depicts an absorption at $347 \mathrm{~nm}$, which is blue shifted compared to the bulk $\mathrm{ZnO}$ whose absorption edge is observed at $380 \mathrm{~nm}$. With an increase in temperature, there is a systematic shift in the absorption edge towards higher wavelength side but the maximum shift occurrs between temperatures of $300{ }^{\circ} \mathrm{C}$ and $500{ }^{\circ} \mathrm{C}$. The absorption edge values corresponding to the samples annealed at $300{ }^{\circ} \mathrm{C}$ and
$500{ }^{\circ} \mathrm{C}$ are $355 \mathrm{~nm}$ and $370 \mathrm{~nm}$. This gradual red shift of absorption edge with increase in annealing temperature is obviously due to the increase of particle size. This indicates the strong quantum confinement effects of the porous $\mathrm{ZnO}$ nanoparticles. The particle size has also been calculated from the absorption edge values of all the three samples according to Ref. [2]. The effective mass model has been used for finding particle size of $\mathrm{ZnO}$ nanoparticles. This model utilizes the fact that the wavelength of absorption depends on particle size. The particle sizes obtained for all the three samples are $5 \mathrm{~nm}, 7 \mathrm{~nm}$ and $13 \mathrm{~nm}$, repectively. The particle size values for the as-prepapred sample and sample calcined at $300{ }^{\circ} \mathrm{C}$ are in good agreement with the values measured from XRD. But in the case of

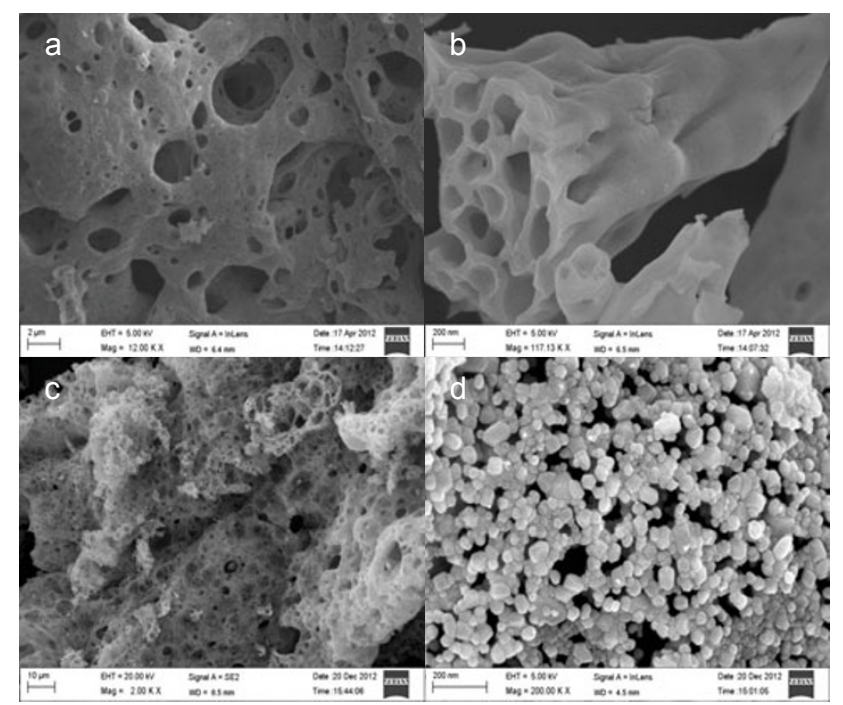

Fig. 2 FE-SEM pictures of the as-prepared porous $\mathrm{ZnO}((\mathrm{a})$ and (b)) and porous $\mathrm{ZnO}$ annealed at $500{ }^{\circ} \mathrm{C}((\mathrm{c})$ and $(\mathrm{d}))$.

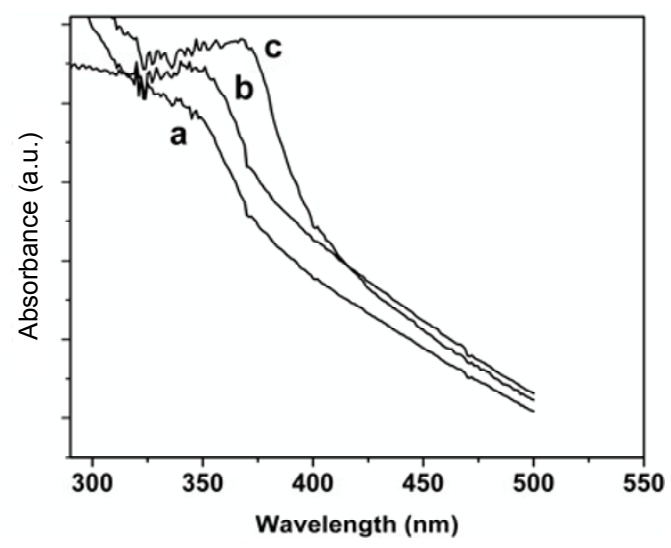

Fig. 3 UV-Vis absorption spectra of (a) the as-prepared porous $\mathrm{ZnO}$ and porous $\mathrm{ZnO}$ calcined at (b) $300{ }^{\circ} \mathrm{C}$ and (c) $500{ }^{\circ} \mathrm{C}$. 
the sample calcined at $500{ }^{\circ} \mathrm{C}$, the particle size calculated from UV-Vis absorbance spectrum is not coinciding with the results obtained from FE-SEM and XRD.

\section{4 FT-IR analysis}

The FT-IR spectra of the samples measured in the range of $4000-400 \mathrm{~cm}^{-1}$ are presented in Fig. 4. The as-prepared $\mathrm{ZnO}$ shows IR peaks at $457 \mathrm{~cm}^{-1}$, $1063 \mathrm{~cm}^{-1}, 1390 \mathrm{~cm}^{-1}, 1602 \mathrm{~cm}^{-1}$ and $3423 \mathrm{~cm}^{-1}$. The sharp peak positioned at $457 \mathrm{~cm}^{-1}$ is attributed to the $\mathrm{Zn}-\mathrm{O}$ stretching bonds. The IR bands shown in Fig. 4 are in the region of $1700-600 \mathrm{~cm}^{-1}$ and correspond to $\mathrm{C}=\mathrm{O}, \mathrm{C}-\mathrm{O}$ and $\mathrm{C}-\mathrm{H}$ vibrations respectively [16]. Remaining peaks are due to the $\mathrm{O}-\mathrm{H}$ stretching vibrations and bending modes of the adsorbed water. With the increase of temperature, the intensity of peaks centered at $1063 \mathrm{~cm}^{-1}, 1390 \mathrm{~cm}^{-1}$ and $1602 \mathrm{~cm}^{-1}$ are deteriorated and at $500{ }^{\circ} \mathrm{C}$ these peaks are almost disappeared. It indicates that organic species are completely removed at $500{ }^{\circ} \mathrm{C}$. It is observed that the position of $457 \mathrm{~cm}^{-1}$ peak remains the same when annealed at $300{ }^{\circ} \mathrm{C}$ but shifts to $439 \mathrm{~cm}^{-1}$ at $500{ }^{\circ} \mathrm{C}$. The shift of the XRD peaks is also observed between $300{ }^{\circ} \mathrm{C}$ and $500{ }^{\circ} \mathrm{C}$, which is attributed to the compressive stress acting on $\mathrm{ZnO}$ nanoparticles. So, the broadening and shift of the IR peak to lower wavenumber could be due to the stress acting on $\mathrm{ZnO}$ nanoparticles and variation in morphology. Figure 4(b) shows the FT-IR spectrum of porous $\mathrm{ZnO}$ calcined at

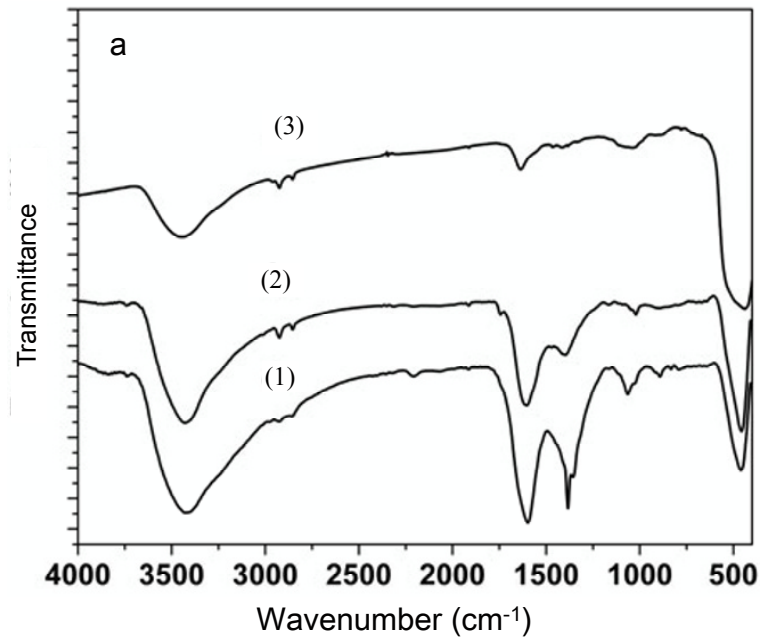

$400{ }^{\circ} \mathrm{C}$ at a heating rate of $1{ }^{\circ} \mathrm{C} / \mathrm{min}$ along with its FE-SEM micrograph. It is apparent from the micrograph that the initial particles are spherical in shape with an approximate size of $9 \mathrm{~nm}$. This size seems to be critical and if once reaching that size, they tend to agglomerate to bigger particles. These nanoparticles grow to larger sizes at the expense of other small paraticles through Ostwald ripening process. Interestingly, the sharp peak at $457 \mathrm{~cm}^{-1}$ splits into two peaks positioned at $518 \mathrm{~cm}^{-1}$ and $682 \mathrm{~cm}^{-1}$. Similar results are observed in the case of $\mathrm{ZnO}$ microcrystals and the position of the peaks is dependent on axial ratio $(c / a)$ of the crystals [17]. The FE-SEM picture of this sample shows the change of morphology of $\mathrm{ZnO}$ nanoparticles from spherical to cylinder shape, so the splitting of $\mathrm{Zn}-\mathrm{O}$ stretching band in FT-IR spectrum can be assigned to the change in morphology of $\mathrm{ZnO}$ nanoparticles. It is obvious from FT-IR spectrum of porous $\mathrm{ZnO}$ calcined at $400{ }^{\circ} \mathrm{C}$ at a heating rate of $1{ }^{\circ} \mathrm{C} / \mathrm{min}$ that organic species are not eliminated at this temperature.

\section{5 PL analysis}

Room-temperature PL spectra of the samples recorded at an excitation wavelength of $320 \mathrm{~nm}$ are shown in Fig. 5. All the samples exhibit near UV emission at around $397 \mathrm{~nm}$ and four defect related peaks at $437 \mathrm{~nm}$, $466 \mathrm{~nm}, 492 \mathrm{~nm}$ and $527 \mathrm{~nm}$. The intensity of all these emission peaks is enhanced with the rise of temperature. It can be seen from the figure that there is no significant change in the emission intensities of the

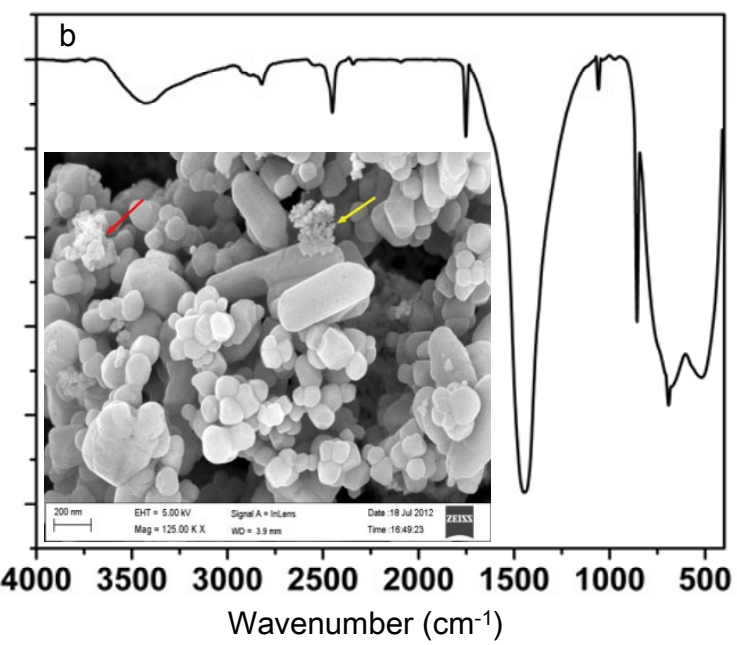

Fig. 4 (a) FT-IR spectra of (1) the as-prepared porous $\mathrm{ZnO}$ and porous $\mathrm{ZnO}$ calcined at (2) $300{ }^{\circ} \mathrm{C}$ and (3) $500{ }^{\circ} \mathrm{C}$; (b) FT-IR spectrum of the sample calcined at $400{ }^{\circ} \mathrm{C}$ with a heating rate of $1{ }^{\circ} \mathrm{C} / \mathrm{min}$ and inset shows the FE-SEM picture of the sample. 


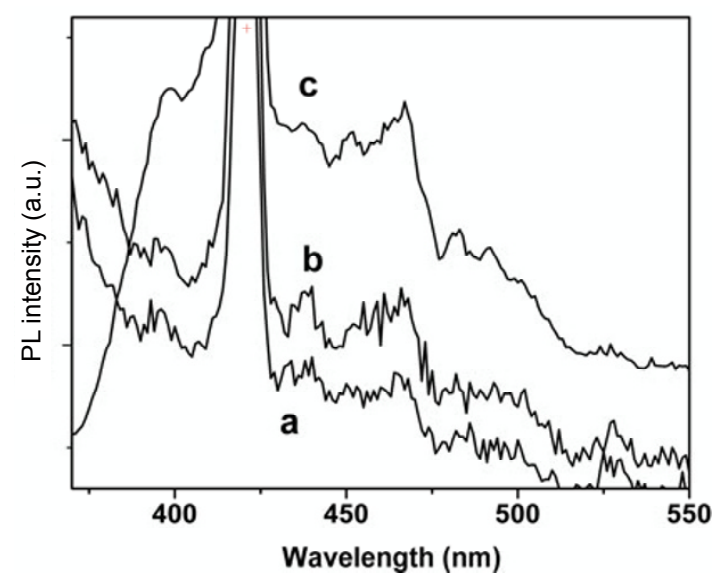

Fig. 5 PL spectra of (a) the as-prepared porous $\mathrm{ZnO}$ and porous $\mathrm{ZnO}$ calcined at (b) $300{ }^{\circ} \mathrm{C}$ and (c) $500{ }^{\circ} \mathrm{C}$.

as-prepared porous $\mathrm{ZnO}$ and porous $\mathrm{ZnO}$ calcined at $300{ }^{\circ} \mathrm{C}$. But when the temperature is increased to $500{ }^{\circ} \mathrm{C}$, the intensities of emission peaks are enhanced remarkably. Very recently, it was proved that $398 \mathrm{~nm}$ peak is originated from the electron transition from the localized level, slightly below conduction band to the valence band [18]. The enhanced intensity of these emission peaks is obviously due to the improved crystallanity of the $\mathrm{ZnO}$ with rise of temperature as confirmed from XRD, FE-SEM and UV-Vis results. The enhancement of the defect related emission intensities along with the UV emission indicates that these defects are intrinsic in nature. The emission peak at $437 \mathrm{~nm}$ can be attributed to the zinc vacancy [19]. The other visible emission peaks at $466 \mathrm{~nm}, 492 \mathrm{~nm}$ and $527 \mathrm{~nm}$ have been assigned to various deep level defect states originated from the zinc interstitials and/or oxygen vacancies $[5,19]$.

\section{Conclusions}

Porous $\mathrm{ZnO}$ was synthesized by a simple method using zinc nitrate, ethanol and TEA. The as-prepared sample contained both nano and micro pores. The nano pores were disappeared but microporosity of the sample was retained even at $500{ }^{\circ} \mathrm{C}$. It was found that the shape of the FT-IR spectrum depends on the size and morphology of $\mathrm{ZnO}$ nanoparticles. The stress and change in morphology were responsible for the shift of $\mathrm{Zn}-\mathrm{O}$ stretching mode to lower wavenumber side. The absorption spectra showed continuous red shift from $347 \mathrm{~nm}$ to $370 \mathrm{~nm}$ with rise of temperature. PL emission intensity enhanced with increase of temperature. The near UV emission at $397 \mathrm{~nm}$ has been attributed to the electron transition from the localized level slightly below conduction band to the valence band. The visible emission at $437 \mathrm{~nm}$ was attributed to the zinc vacancy. The other visible emissions at $466 \mathrm{~nm}, 492 \mathrm{~nm}$ and $527 \mathrm{~nm}$ were assigned to the zinc interstitials and/or oxygen vacancies.

\section{Acknowledgements}

The authors thank the dean of School of Physics, University of Hyderabad, for providing FE-SEM facility generously, and are also grateful to Y. B. Ravi Shankar for his continuous support in XRD analysis of the samples.

Open Access: This article is distributed under the terms of the Creative Commons Attribution Noncommercial License which permits any noncommercial use, distribution, and reproduction in any medium, provided the original author(s) and source are credited.

\section{References}

[1] Service RF. Will UV lasers beat the blues? Science 1997, 276: 895.

[2] Singh AK, Viswanath V, Janu VC. Synthesis, effect of capping agents, structural, optical and photoluminescence properties of $\mathrm{ZnO}$ nanoparticles. J Lumin 2009, 129: 874-878.

[3] Koch U, Fotik A, Weller H, et al. Photochemistry of semiconductor colloids. Preparation of extremely small $\mathrm{ZnO}$ particles, fluorescence phenomena and size quantization effects. Chem Phys Lett 1985, 122: 507-510.

[4] Djurišić AB, Leung $\mathrm{YH}$, Tam KH, et al. Green, yellow, and orange defect emission from $\mathrm{ZnO}$ nanostructures: Influence of excitation wavelength. Appl Phys Lett 2006, 88: 103107.

[5] Jamali-Sheini F. Chemical solution deposition of $\mathrm{ZnO}$ nanostructure films: Morphology substrate angle dependency. Ceram Int 2012, 38: 3649-3657.

[6] Wei A, Sun XW, Xu CX, et al. Growth mechanism of tubular $\mathrm{ZnO}$ formed in aqueous solution. Nanotechnology 2006, 17: 1740-1744.

[7] Wu L, Wu Y, LÜ W. Preparation of $\mathrm{ZnO}$ nanorods and optical characterizations. Physica E 2005, 28: 
76-82.

[8] Roy VAL, Djurišić AB, Chan WK, et al. Luminescent and structural properties of $\mathrm{ZnO}$ nanorods prepared under different conditions. Appl Phys Lett 2003, 83: 141-143.

[9] Kılıç B, Gür E, Tüzemen S. Nanoporous ZnO photoelectrode for dye-sensitized solar cell. J Nanomater 2012, DOI: 10.1155/2012/474656.

[10] Li B, Wang Y. Hierarchically assembled porous $\mathrm{ZnO}$ microstructures and applications in a gas sensor. Superlattice Microst 2011, 49: 433-440.

[11] Jeon SM, Kim MS, Cho MY, et al. Fabrication of porous $\mathrm{ZnO}$ nanorods with nano-sized pores and their properties. J Korean Phys Soc 2010, 57: 1477-1481.

[12] Dai Z, Liu K, Tang Y, et al. A novel tetragonal pyramid-shaped porous $\mathrm{ZnO}$ nanostructure and its application in the biosensing of horseradish peroxidase. J Mater Chem 2008, 18: 1919-1926.

[13] Liu Z, Jin Z, Li W, et al. Preparation of porous $\mathrm{ZnO}$ plate crystal thin films by electrochemical deposition using PS template assistant. Mater Lett 2006, 60: 810-814.

[14] Li S, Zhang X, Jiao X, et al. One-step large-scale synthesis of porous $\mathrm{ZnO}$ nanofibers and their application in dye-sensitized solar cells. Mater Lett 2011, 65: 2975-2978.

[15] Ching CG, Ooi PK, Ng SS, et al. Fabrication of porous $\mathrm{ZnO}$ via electrochemical etching using 10 wt \% potassium hydroxide solution. Mat Sci Semicon Proc 2013, 16: 70-76.

[16] Xiong H-M, Shchukin DG, Möhwald H, et al. Sonochemical synthesis of highly luminescent zinc oxide nanoparticles doped with magnesium(II). Angew Chem Int Edit 2009, 48: 2727-2731.

[17] Andrés Vergés M, Mifsud A, Sernad CJ. Formation of rod-like zinc oxide microcrystals in homogeneous solutions. J Chem Soc Faraday Trans 1990, 86: 959-963.

[18] Sowri Babu K, Ramachandra Reddy A, Sujatha Ch, et al. Optimization of UV emission intensity of $\mathrm{ZnO}$ nanoparticles by changing the excitation wavelength. Mater Lett 2013, 99: 97-100.

[19] Giri PK, Bhattacharyya S, Singh DK, et al. Correlation between microstructure and optical properties of $\mathrm{ZnO}$ nanoparticles synthesized by ball milling. J Appl Phys 2007, 102: 093515. 